\title{
The Determination of the Penetrating Radiation Dose at Hanford
}

\author{
L. A. Rathbun
}

September 1989

Prepared for

the U.S. Department of Energy

under Contract DE-AC06-76RLO 1830

Pacific Northwest Laboratory

Richland, Washington 99352

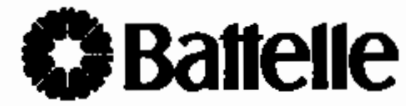




\title{
DISCLAIMER
}

This program was prepared as an account of work sponsored by an agency of the United States Government. Neither the United States Government nor any agency thereof, nor Battelle Memorial Institute, nor any or their employees, makes any wananty, expressed or implied, or assumes any legal liability or responsibility for the accuracy, completeness, or usefuiness of any information, apparatus, product, or process disclosed, or represents that its use would not infringe privately owned rights. Reference herein to any specific commercial product, process, or service by trade name, trademark, manufacturer, or otherwise, does not necessarily constitute or imply its endorsement, recommendation, or favoring by the United States Government of any agency thereof, or Battelle Memorial Institute. The views and opinions of authors expressed herein do not necessarily state or reflect those of the United States Government or any agency thereof.

\author{
PACIFIC NORTHWEST LABORATORY \\ operated by
BATTELLE MEMORIAL INSTITUTE
for the
UNITED STATES DEPARTMENT OF ENERGY
under Contract DE-ACO6-76RLO 1830

Printed in the United States of America

Available to DOE and DOE contractors from the

Office of Scientific and Technical Information, P.O. Box 62, Oak Ridge, TN 37831; prices available trom (615) 576-8401. FTS 626-8401.

Available to the public from the National Technical Information Service,

U.S. Deparment of Commerce, 5285 Port Royal Rd., Spring field, VA 22161.

NTIS Price Codes, Microfiche A01

\begin{tabular}{|c|c|}
\hline \multicolumn{2}{|c|}{ Printed Copy } \\
\hline Pages & $\begin{array}{l}\text { Price } \\
\text { Codes }\end{array}$ \\
\hline $001-025$ & $\mathrm{~A} 02$ \\
\hline $026-050$ & $\mathrm{~A} 03$ \\
\hline $05 \div-075$ & $\mathrm{~A} 04$ \\
\hline $076-100$ & A05 \\
\hline $10 \%-125$ & A06 \\
\hline $126-150$ & $\mathrm{~A} 07$ \\
\hline $151-175$ & $\mathrm{~A} 0 \mathrm{~B}$ \\
\hline $176-200$ & $\mathrm{~A} 09$ \\
\hline $201-225$ & $A 10$ \\
\hline $226-250$ & A11 \\
\hline $251-275$ & A 12 \\
\hline $276-300$ & A13 \\
\hline
\end{tabular}


PNL-7124

UC -600

THE DETERMINATION OF THE PENETRATING

RADIATION DOSE AT HANFORD

L. A. Rathbun

September 1989

Prepared for the U.S. Department of Energy under Contract DE-AC06-76RLO 1830

Pacific Northwest Laboratory

Richland, Washington 99352 
$\because$ 
SUMMARY

Most of the thermoluminescent dosimeters (TLDs) and other devices that have been used to measure environmental radiation on the Hanford Site have measured natural background levels of radiation. Measurements of offsite environmental radiation near the boundary of the Hanford Site have of ten indicated higher doses than onsite measurements have. However, the converse has been found when radiation measurements from the cities and communities of southeastern Washington were compared with onsite measurements.

The historical trends described for environmental TLD data have been better defined in this study by compiling the ILD data for selected locations over a 6-year period (1983 to 1988). The ongoing Hanford Environmental Surveillance Program also provides radionuclide concentrations in soil based on samples collected by technicians at Pacific Northwest Laboratory (PNL) and sent to a comnercial laboratory for analyses.

As part of the study described in this report, a portable gamma spectroscopy system was used in the field to identify concentrations of gammaemitting radionuclides in the soil at various locations on the Hanford Site and in the surrounding area. This work began in 1986. Supplemental radiation measurements were made with a microprocessor-based survey meter and large NaI detector.

Average annual dose rates were calculated on the Hanford Site, at the perimeter of the site, and at surrounding communities for each measurement device. There was little variation $(<10 \%)$ based on the type of measurement device.

Given the currently accepted value of $30 \mathrm{mrad} / \mathrm{yr}$ for the outdoor ionizing component of cosmic radiation, the best estimate of the average annual background dose rate on the Hanford site is $80 \mathrm{mrad} / \mathrm{yr}$. No increases in offsite dose due to Hanford operations were found. The dose rate at the site perimeter is approximately $10 \%$ higher because of naturally occurring higher concentrations of potassium and thorium. The dose rate at surrounding cities and communities is approximately $7 \%$ lower than the onsite dose rate because of the paving and graveling near the sites where measurements were made. 
It is recommended that additional environmental monitoring data be collected with the measurement devices described in this report. Additionally, continuous monitoring of a few selected locations should be performed with pressurized ionization chambers that have been precisely calibrated to measure $10-\mu \mathrm{R} / \mathrm{h}$ dose rates. One of these devices should be used to measure the dose rate several times a year in the middle of the Columbia River below Richland to assess the dose from cosmic radiation.

Thermoluminescent dosimeters placed at city and community locations should be moved away from paved and graveled areas and other disturbed locations that would not reflect the true natural radiation background for the area. This would allow for a more valid comparison of Hanford and offsite doses. 


\section{ACKNOWLEDGMENTS}

The efforts of $M$. Cross and R. E. Durham in report assembly are appreciated. Advice from J. J. Fix and editorial comments from S. K. Ennor,

R. E. Jaquish, J. R. Weber, and R. J. Traub are gratefully acknowledged. 


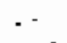




\section{CONTENTS}

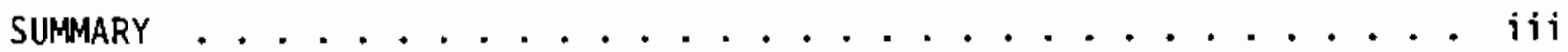

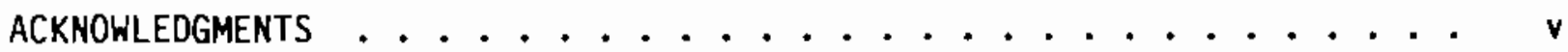

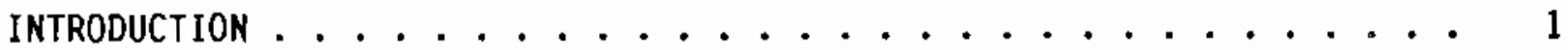

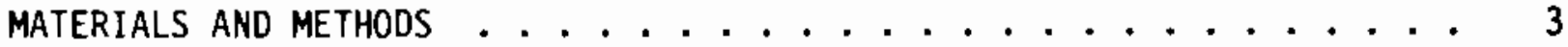

GAMMA SPECTROSCOPY SYSTEM ................ 3

GAMMA SURVEY INSTRUMENT . . . . . . . . . . . . 5

THERMOLUMINESCENT DOSIMETERS . . . . . . . . . 7

RADIONUCLIDES IN SOIL .................. 8

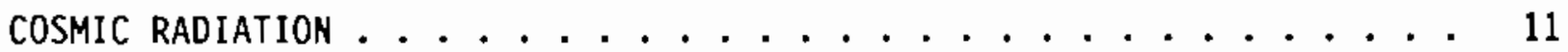

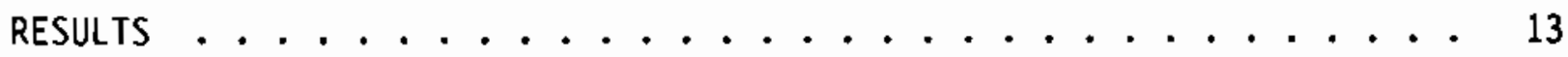

GAMMA SPECTROSCOPY SYSTEM ................. 13

GAMMA SURVEY INSTRUMENT ....................... 13

THERMOLUMINESCENT DOSIMETERS . . . . . . . . . 15

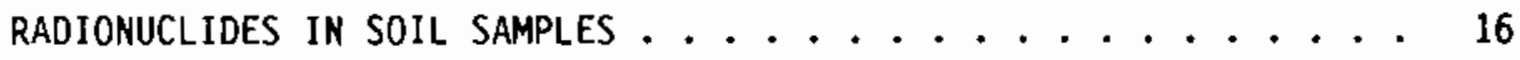

COMPARISONS OF YEARLY ENVIRONMENTAL DOSES .............. 19

CONCLUSIONS AND RECOMMENDATIONS ................. 21

REFERENCES ....................... 23 



\section{FIGURES}

1 Equipment Arrangement for the Photon Spectrometer . . . . . . 3

2 Environmental Dosimeter Locations at the Site Perimeter and at Nearby and Distant Commuities . . . . . . . . . . . 9

3 Long-term Average Outdoor Dose Rate from Cosmic Radiation at Ground Altitudes . . . . . . . . . . . . . 12

4 In Situ Germanium Detector Spectra for an Onsite Location . . . . . . . . . . . . . . . . . 14

\section{$\underline{\text { TABLES }}$}

1 Reported Dose Rates for Unit Quantities of Natural Nuclides........................ 6

2 Environmental Doses Derived from Detectors, Soil, and TLDs . . . 17

3 Radionuclide Concentrations in Soil ............ 18 


\section{INTRODUCTION}

Dose rates from penetrating radiation (primarily gamna rays) have been measured on the Hanford Site and surrounding areas since 1956. Since 1963, thermoluminescent dosimeters (TLDs) have been the primary measurement devices used for this purpose. At most stations the radiation measured on the TLDs was primarily from natural sources. Only a few TLDs near operating facilities and waste disposal areas measured increases above background radiation. It became apparent early in the history of environmental monitoring at Hanford that background radiation on the Hanford Site was less intense than it was imnediately beyond the perimeter of the site. The lowest doses, however, have been measured by TLDs placed in the cities and communities of southeastern Washington.

The purpose of the study described herein was to accurately determine environmental dose rates at a variety of offsite and onsite locations, to compare average dose rates by location, and to determine the radionuclides responsible for the environmental dose rates determined. This study was performed as part of the Environmental External Radiation Monitoring Dosimetry Task of the ongoing Surface Environmental Monitoring Project (SEMP), which has been conducted by the Pacific Northwest Laboratory(a) (PNL) for DOE.

For this report, the SEMP has provided environmental TLD data from selected locations over a 6-year period (1983 to 1988). This program has also provided data for the present report on radionuclide concentrations in soil, for which the traditional uranium analyses have been supplemented by analyses for $232 \mathrm{Th}$ and $40 \mathrm{~K}$ since 1984 . Doses from reported concentrations of radionuclides in soil were derived for this report by multiplying the concentration by the appropriate conversion factor.

In addition to using recent data from the HES program, this report describes the field use of a portable gamma spectroscopy system that identifies concentrations of gamma-emitting radionuclides in the soil at

(a) Pacific Northwest Laboratory is operated by Battelle Memorial Institute for the U.S. Department of Energy under Contract DE-AC06-76RLO 1830. 
various locations on the Hanford Site and in the surrounding area. This work began in 1986 and was augmented by computer software in 1987 that made analyses of the spectra much less time-consuming. In addition, a large NaI detector was matched with a microprocessor-based survey meter to provide quick and reliable estimates of the gamma dose rates at TLD locations.

The following sections contain discussions of the study methods, the field equipment used and its calibration, the effects of background cosmic radiation, and the results of dose calculations from field readings and previous studies. Finally, doses are compared with studies of other years, and the findings are summarized with specific recommendations for further study. 


\section{MATERIALS AND METHODS}

Data on TLDs and soil sampling were taken from published PNL documents and associated computer databases. The TLD measurements and soil sampling were performed independently of the study reported here. Two other sources of data (gamma spectroscopy and survey meter measurements) were the actual field measurements conducted as part of the study described in this report. The instruments, their calibration and application during this study, are described in the following subsections.

\section{GAMMA SPECTROSCOPY SYSTEM}

The photon spectrometer (gamma spectroscopy system) used during this study consisted of a hyperpure germanium crystal, a high-voltage power supply, a preamplifier, an amplifier, and an multichannel analyzer (MCA), as diagrammed in Figure 1. The germanium detector required high-voltage input and preamplifier power. The signal was taken from the preamplifier and input to the amplifier built into the MCA system. The amplitude of each signal pulse was measured and stored in a channel number proportional to the pulse height. During field measurements, data were also stored either on magnetic tape or in a portable computer. The data were transferred to the analysis computer after the measurements were completed.

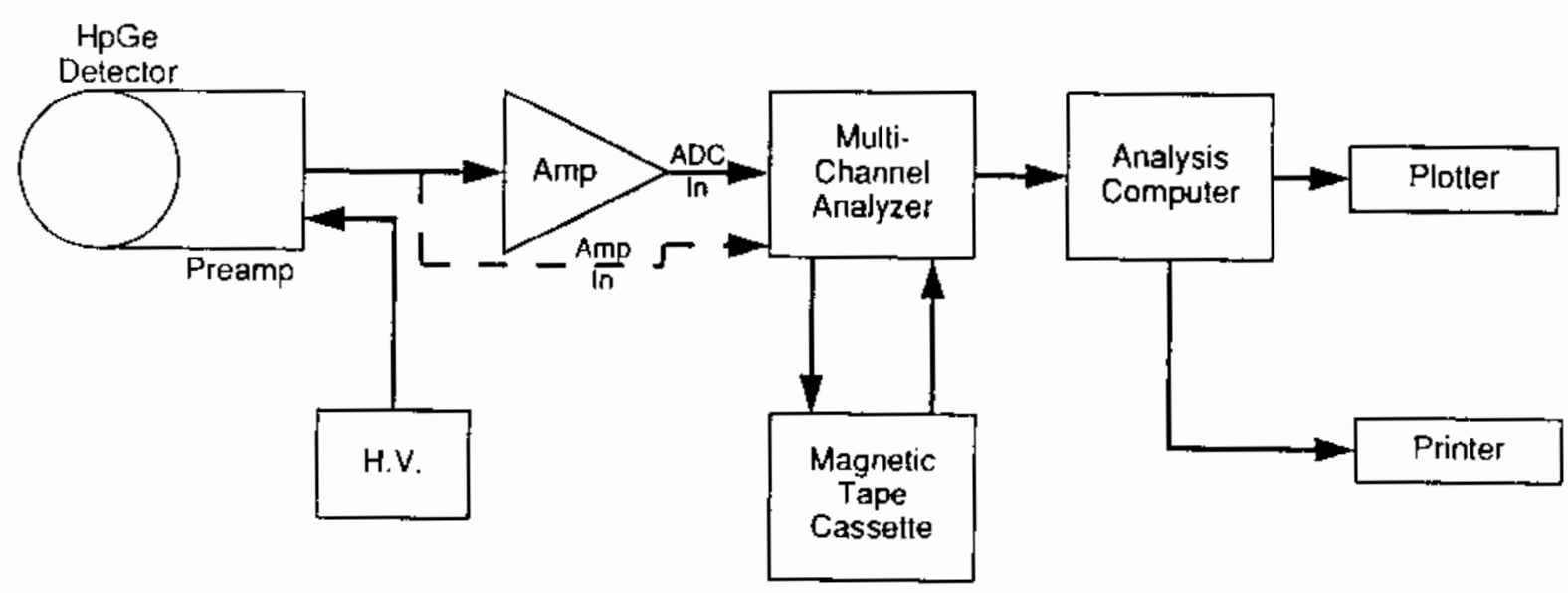

FIGURE 1. Equipment Arrangement for the Photon Spectrometer 
During calibration of the germanium detector (photon spectrometer). radioactive sources of known activity $(\sim 1 \mu \mathrm{Ci})$ were placed 1 m from the detector and spectra were obtained. For each source, the net count rate (total count rate minus Compton background) in the full energy peak was obtained. The source emission rates were corrected for decay that occurred up to the time of counting. The full energy peak efficiencies were calculated as suggested in American National Standards Institute (ANSI) Standard N42.14-1978 (ANS1 1978). The efficiency was measured using radioisotope mixtures with known relative photon intensities up to about $2 \mathrm{MeV}$.

The use of gamma spectroscopy detectors is a widely accepted method of determining the activity of nuclides that emit gamma radiation. In a laboratory situation, the gamma spectroscopy detector can be accurately calibrated with small radioactive sources of known activity placed at specific distances. The full energy efficiency curve versus gamma-ray energy for the gamma spectroscopy detector can then be used to determine the activity of comparably sized field samples placed at the same distances. When the ganma spectroscopy detector is placed outdoors $1 \mathrm{~m}$ high (or at any given height), it measures the dose from a semi-infinite plane. One cannot subtract the "background" contribution as one would in the laboratory, because the background is what is being measured. The actual volume of the outdoor background or in situ sample is limited by the finite range of gamma rays in air, soil, and any other intervening material. Because of the wide range of gamma energies found in the environment and variations in soil density, radon emanation, and other parameters, it is very difficult to quantify the size of the in situ sample. While attenuation of gamma rays within the sample itself is generally a small or nonexistent problem in the laboratory, it is the major problem for in situ environmental measurements. The full energy gamma peaks in an environmental spectrum will typically be $1 / 3$ to $1 / 2$ the relative magnitude of peaks in a spectrum obtained with the same detector and a small soil sample representative of the in situ environment. The missing portions of the full energy peaks will show up as Compton scattering events.

The problem of ganma attenuation has been addressed by using a collimator to limit the view of the detector (Cutshall and Larsen 1986) or by applying a combination of experimental and theoretical methods (Beck, 
DeCampo, and Gogolak 1972). The latter procedure is referenced and described in Environmental Radiation Measurements (NCRP 1976) and updated by Helfer and Miller (1988). This study used a combination of experimental and theoretical methods, as cited above.

The gamma spectrometer was taken to traditional soil sampling and TLD monitoring locations around the hanford Site. The detector was placed $1 \mathrm{~m}$ above the surface of the ground. One-hour and one and a-half hour spectra were obtained and stored with the photon spectroscopy system. The field measurements and the subsequent data analyses and interpretation comprised the major portion of the task. The conversion of observed peak count rates from collected spectra to radionuclide concentrations in soil proceeded in the following manner.

The basic calibration equation for in situ spectrometry can be expressed in terms of peak count rate $(N)$, activity or inventory in the soil (A), and uncollided flux $(\phi)$ as

$$
\left.N_{f} / A=\left(N_{f} / N_{0}\right) N_{0} / \phi\right)(\phi / A)
$$

where the fundamental calibration parameters are expressed in ratios as follows:

$\mathrm{Nf} / \mathrm{A}$ is the total-absorption peak count rate (cpm) in the spectrum at the energy of a particular nuclide $\gamma$ transition per unit inventory ( $\mathrm{Bq} \mathrm{m}^{-2}$ ) or concentration ( $\left.\mathrm{Bq} \mathrm{g}-1\right)$ of that nuclide in the soil

$\mathrm{Nf} / \mathrm{N}_{0}$ is the angular correction factor of the detector at that energy for a given source distribution in the soil

$N_{0} / \phi$ is the peak count rate (cpm) per unit uncollided flux $(\gamma \mathrm{cm}-2$ $s^{-1)}$ for a parallel beam of $y$ rays of the same energy that is incident-normal to the detector face

$\phi / A$ is the total uncollided flux $\left(\gamma \mathrm{cm}^{-2} \mathrm{~s}^{-1}\right)$ at that energy arriving at the detector per unit inventory or concentration of the nuclide in the soil

Most of the steps involved in using the equation just described can be saved by using the appropriate tables (Helfer and Miller 1988). No/A values are listed for common natural radionuclides and various detector efficiencies. 
These $\mathrm{N}_{0} / \mathrm{A}$ values represent the peak count rates to inventory or concentration conversion factor for a detector where $\mathrm{N}_{f} / \mathrm{N}_{0}=1$, that is, where there is no angular correction factor. Also listed in these tables are the factors to convert the inventory or concentration to exposure rate and dose rate in air at a height of $1 \mathrm{~m}$ above the ground. These factors were converted to common units and listed in Table 1 of this report. The detector used in these studies was dowmward facing. It had an efficiency of $11.1 \%$ (relative to a $3 \times 3 \mathrm{in}$. NaI detector at $1332 \mathrm{keV}$ ) and a length-to-diameter ratio of 0.98 . These are the important parameters used in determining radionuclide concentrations and doses. Because only the peaks in the gamma spectra collected were analyzed, no information about the continuum of cosmic radiation energies was available. Therefore, a cosmic ray contribution of $30 \mathrm{mrem} / \mathrm{yr}$ was obtained from the latest NCRP guidance on the subject (NCRP 1987) and was added to the dose due to terrestrial radiation.

IABLE 1. Reported Dose Rates for Unit Quantities of Natural Nuclides

\begin{tabular}{|c|c|c|c|}
\hline \multirow[b]{2}{*}{ Source } & \multicolumn{3}{|c|}{$\mu \mathrm{rem} / \mathrm{h}$} \\
\hline & $\begin{array}{r}238 \mathrm{U} \\
1 \mathrm{ppm}\end{array}$ & $\begin{array}{l}232 \mathrm{Th} \\
1 \mathrm{ppm}\end{array}$ & $\begin{array}{r}K \\
1 \%\end{array}$ \\
\hline Lovborg et al. (1978) & 0.5 & 0.25 & 1.25 \\
\hline Jasinska, Niewiadomski, and Schwabenthan (1982) & 0.54 & 0.27 & 0.93 \\
\hline Lowder et al. (1972) & 0.77 & 0.33 & 1.73 \\
\hline Helfer and Miller (1988) & 1.29 & 0.31 & 1.48 \\
\hline
\end{tabular}

\section{GAMMA SURVEY INSTRUMENT}

For a quick verification of environmental doses, supplemental monitoring equipment was used. It consisted of a gamma survey instrument (an Eberline Smart Portable [ESP-2]) and a 4-x-4-x-3-in. NaI thallium crystal optically coupled to a photomultiplier tube. The detector assembly was surrounded by thermal and shock insulation and sealed in a polyvinyl chloride housing. The ESP-2 is lightweight and rugged; its battery life is sufficient for hundreds of measurements. The survey meter can store up to 500 data points for subsequent transfer to a printer or computer. A small battery-operated printer has been used with the equipment. 
When properly set up and calibrated, the ESP-2 (with NaI detector) was linear and accurate because of its microcomputer-based design. The calibration procedure included adjusting the high-voltage and -gain potentiometers to optimum values and setting the discriminator to exclude all photons below $370 \mathrm{keV}$. Then, the NaI detector was exposed to ambient environmental radiation, while the dose rate was simultaneously determined with the germanium detector and the calibration constant of the ESP-2 was adjusted to the correct value.

The ESP-2/NaI detector accompanied the gamma spectrometer at nine locations. Separate survey instrument readings were also taken at the $400-E$ Area, Benton City, and Ringold TLD locations. In each case, the detector was placed $1 \mathrm{~m}$ above the surface of the ground. Three counts of 1 minute each were averaged to obtained a dose rate in micro-rem per minute ( $\mu \mathrm{rem} / \mathrm{min})$. This value was multiplied by 525 to obtain millirem per year (mrem/yr).

Because the large NaI detector is used only for photon energies above $370 \mathrm{keV}$ and is calibrated against the gamma spectroscopy spectral doses in the field, the measurement results are very similar to those derived from the gama spectroscopy spectra. The only potential problem would result from a radical shift in the dose ratios of $40 \mathrm{~K}$-uranium-thorium from one location to another.

\section{THERMOLUMINESCENT DOSIMETERS}

Environmental dosimeter results for Hanford monitoring are reported annually by PNL. The TLD data are available in a series of reports entitled "Environmental Monitoring at Hanford" (see, for example, Jaquish and Mitchel1 [1988]). Onsite TLD data are listed in the referenced reports in terms of $m \mathrm{rem} / \mathrm{h}$. These TLD data were converted to $\mathrm{mrem} / \mathrm{yr}$ in this report. Technical details about the construction, deploy-ment, processing, and calibration of environmental dosimeters are also well known and are discussed below.

The environmental radiation dosimeters consisted of five $\mathrm{CaF}_{2}: \mathrm{Mn}$ thermoluminescent chips encased in a plastic capsule. The capsule contained a lead-tantalum filter $(90.051-\mathrm{mm}$ lead and $0.254-\mathrm{mm}$ tantalum) to flatten the 
energy response of the dosimeter. The $\mathrm{CaF}_{2}: \mathrm{Mn}$ TLDs were initially used at Hanford in 1977. Prior to that time, CaF2:Dy TLDs had been used for environmental monitoring. The dosimeters were mounted $1 \mathrm{~m}$ above the ground and most were exchanged every 4 weeks.

The thermoluminescent dosimeters are secondary dosimeters, and they must be calibrated against the primary system of the National Institute of Standards and Technology via a calibrated ionization chamber. A set of calibration dosimeters is prepared for each set of environmental field dosimeters deployed. The exposure of the calibration set is made at approximately the midpoint of the time period for the field deployment. A three-point calibration is performed for the calibration set $(20,40$, and $60 \mathrm{mR}$ of $137 \mathrm{Cs}$ gamma radiation). The calibration dosimeters are kept in a low-background storage vault and the environmental dosimeters are kept at field locations.

The actual TLD processing was conducted by the Instrumentation and External Dosimetry Section of PKL's Health Physics Department. The TLDs used by PNL were screened upon initial receipt to ensure that the sensitivity of each individual detector was within $\star 10 \%$ of the average sensitivity for the batch. The TLD data used in this study were all based on 28-day exposures.

Figure 2 shows the locations of environmental dosimeters around the perimeter of the Hanford Site and in communities in the Northwest.

\section{RADIONUCLIDES IN SOIL}

Much less information was available on the radionuclides in Hanford than was available on TLD measurements. The soil samples were gathered by PNL technicians and sent to a comnerical laboratory for analyses. The analyses were based on gamma spectroscopy similar to the in situ gamma spectroscopy described in this report. However, the radionuclides were chemically separated from the soil samples before analysis. In the case of uranium, this meant that only the soluble fraction (approximately one-half of the total) was analyzed. The soil sample data were obtained from the Environmental Monitoring at Hanford for 1987 (Jaquish and Mitchell 1988) and from PNL data banks. Widespread soil sampling for potassium and 232Th has been performed as part of the Hanford environmental monitoring program only since 1984. 


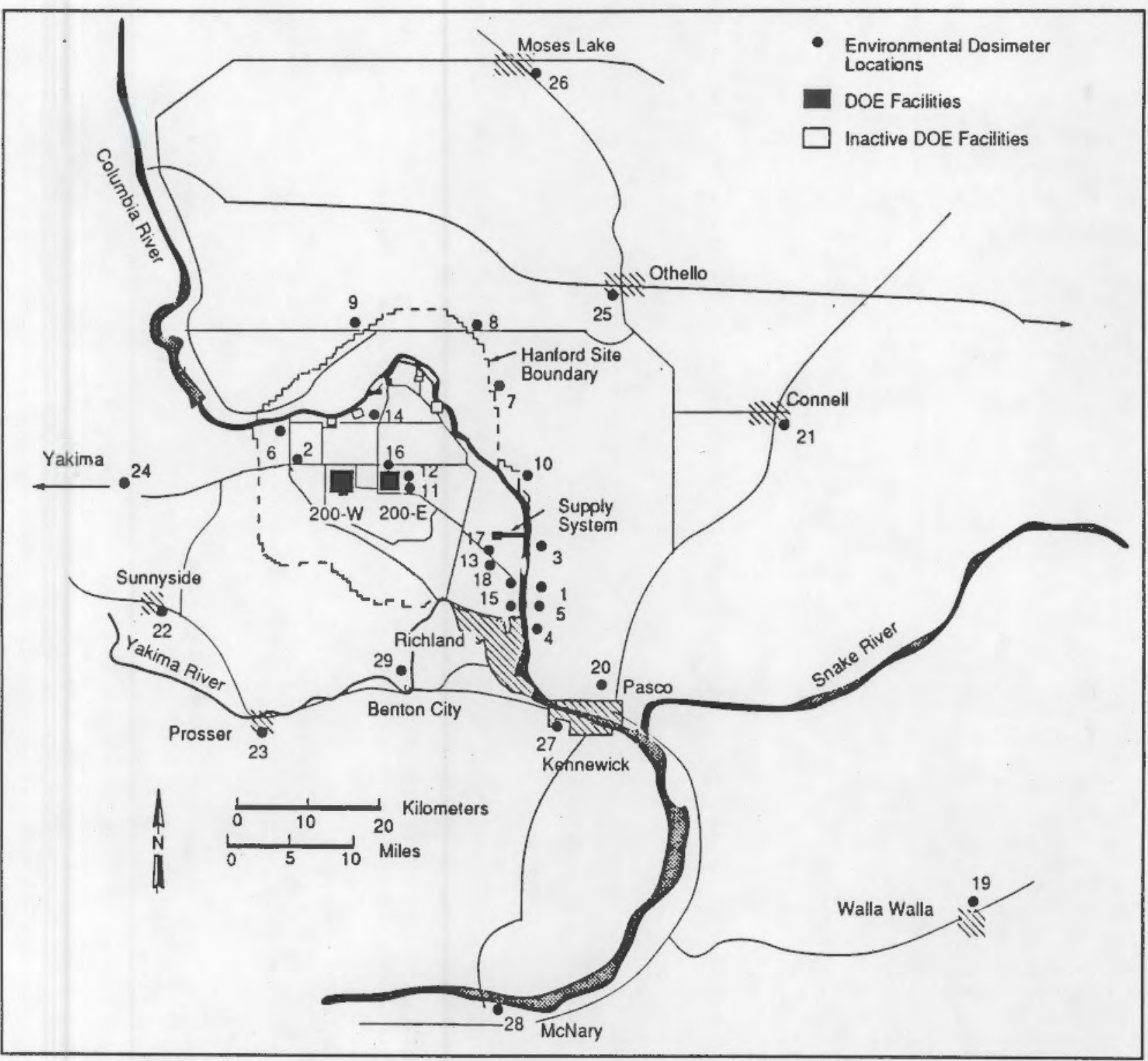

FIGURE 2. Environmental Dosimeter Locations at the Site Perimeter and at Nearby and Distant Communities 



\section{COSMIC RADIATION}

The absorbed dose rate to a person in the outdoor environment from cosmic radiation can be readily calculated for the charged particle components. The muons and associated fast electrons are essentially unattenuated by the body, so that the ratio of the dose rates absorbed by the whole body or organ to those in air depends mainly on the muon and electron stopping powers in the two media. This ratio is only slightly greater than unity, which compensates for any small attenuation. For practical purposes, the air-absorbed dose rate data (see Figure 3 ) can be used without modification to infer the absorbed dose rate within the body. The mean quality factor associated with muons and electrons is also close to unity, so that the same values may be used for dose equivalent rate for the cosmic-ray charged particles.

Calculations of the total charged particle flux density induced by cosmic rays near the surface of the earth have been compared with experimental measurements (0'Brien 1972; Lowder et al. 1972) with reasonable agreement $(* 20 \%)$. At ground elevations and at the latitude range of the continental United States, the variation in cosmic-ray charged-particle intensity due to the geomagnetic field effect is less than $2 \%$ (Carmichael and Berrovitch 1969), while the 11-year variation due to the solar activity cycle has a maximum amplitude of less than $10 \%$ of the mean level. The maximum solar activity corresponds to the minimum cosmic ray intensity and vice versa. During the period of the measurements discussed in this report (1987 to 1988 ), the cosmic ray intensity was approximately $5 \%$ above the mean. The outdoor cosmic ray intensity for the elevation and latitude of the Hanford Site was estimated to be $30 \mathrm{mrem} / \mathrm{yr}$. This agrees well with the average population dose for the United States (NCRP 1987). 


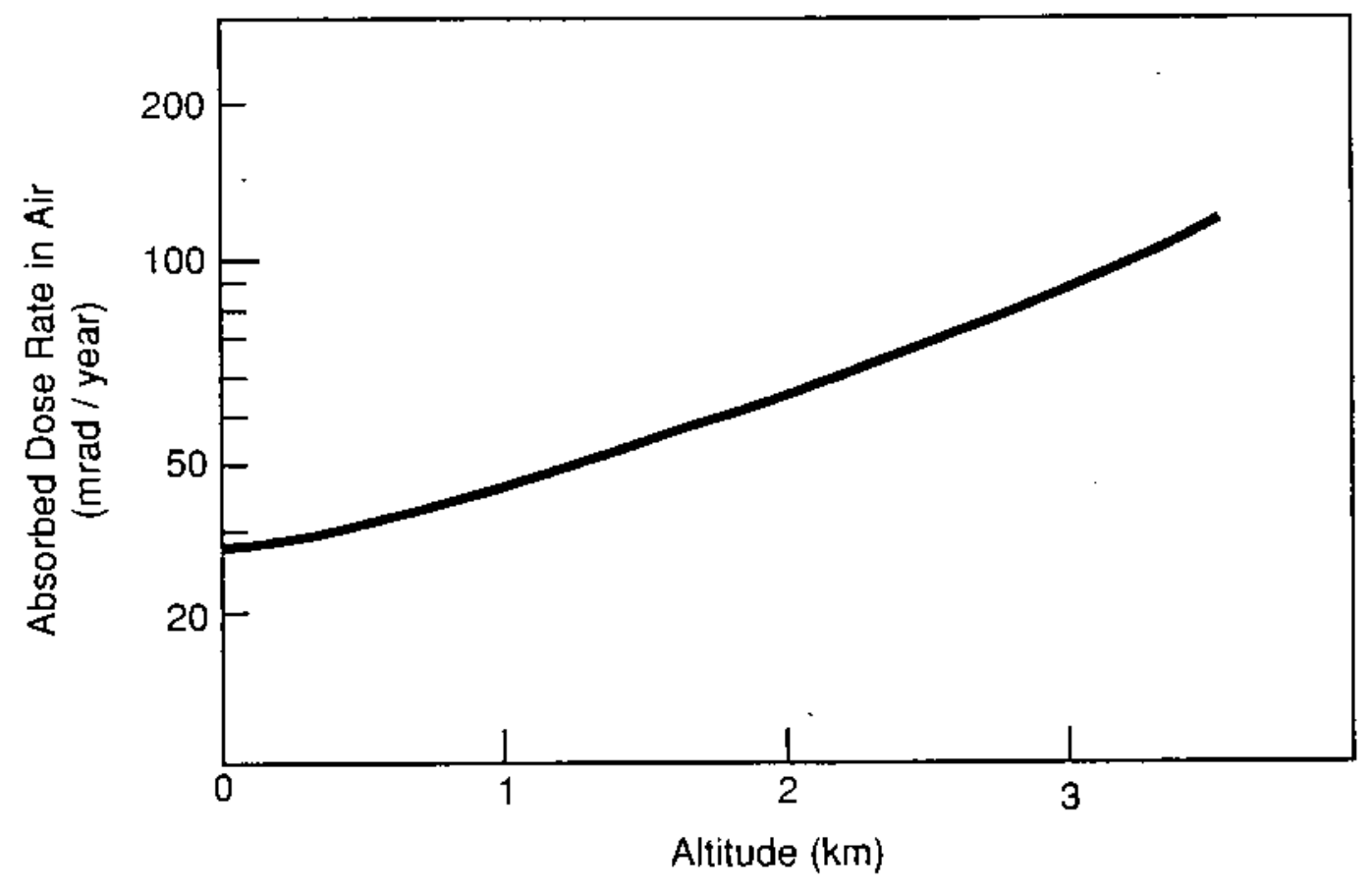

FIGURE 3. Long-term Average Outdoor Dose Rate from Cosmic Radiation at Ground Altitudes. The charged particle absorbed dose rate in air or tissue is shown in the lower curve and the total dose equivalent rate (charged particles plus neutrons) is shown in the upper curve at 5-cm depth in a 30-cm-thick slab of tissue. (Source: NCRP 1987.) 


\section{$\underline{\text { RESULTS }}$}

The following subsections discuss the annual environmental doses due to gamma radiation as determined by in situ gamma spectroscopy (germanium detector), gamma survey instrument (NaI detector) measurements at 19 locations, the TLD data, and soil radioactivity data (the latter two sources of data being independent of the present study).

\section{GAMMA SPECTROSCOPY SYSTEM}

The second column of Table 2 lists the yearly dose (including a 30-mrem/yr cosmic contribution) derived from in situ germanium detector spectra. A representative spectrum is shown in Figure 4. The activity-todose conversion factors are those provided by Helfer and Miller (1988). Total yearly doses averaged $77 \mathrm{mrem}, 88 \mathrm{mrem}$, and $71 \mathrm{mrem}$ for onsite, hanford perimeter, and community/city locations, respectively.

The third column of Table 2 lists the relative percent of total terrestrial dose for $40 \mathrm{~K}$, the uranium series, and the thorium series, as determined by the germanium detector. The average $40 \mathrm{~K}$ dose is approximately $45 \%$ of the total, regardless of the type of location. Uranium and thorium doses are both near 26\% of the total on the Hanford Site, but thorium is more dominant at perimeter and community locations. The contribution to dose from ${ }^{137} \mathrm{Cs}$ and other fission products was approximately $2 \%$ of the total at most locations and approximately $3 \%$ at the locations with the highest fission product concentrations. These low concentrations of fission products are typical of worldwide fallout. No pattern of increased fission products was noted either on the Hanford Site or in the area surrounding the site.

\section{GAMMA SURVEY INSTRUMENT}

The annual average environmental doses measured with the NaI detector (see Table 2, column 8) and the ESP-2 survey meter were $80 \mathrm{mrem}, 81 \mathrm{mrem}$, and 72 mrem for onsite, perimeter, and community locations, respectively. 


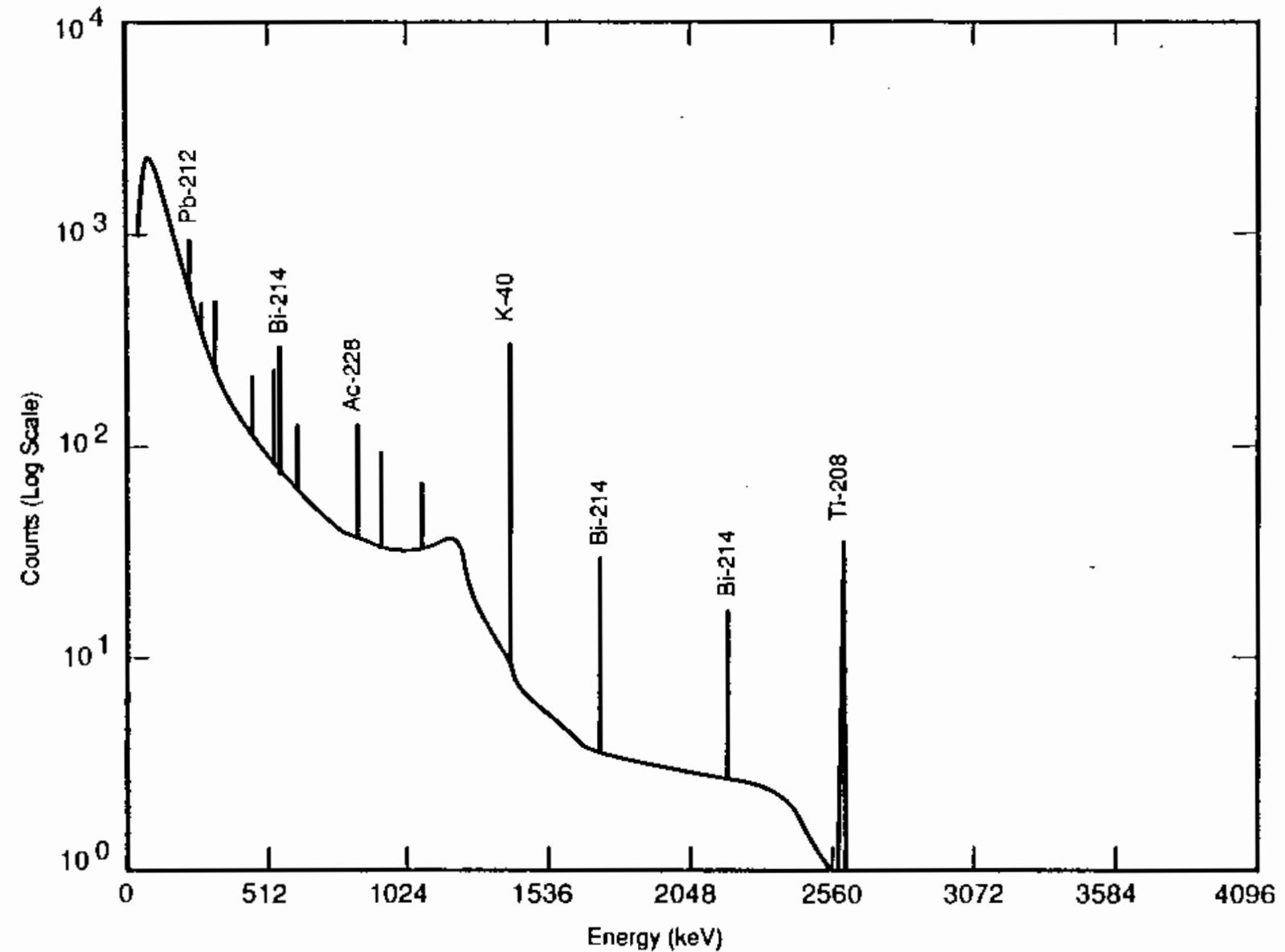

FIGURE 4. In Situ Germanium Detector Spectra for an Onsite Location (300 Area) 


\section{THERMOLUMINESCENT DOSIMETERS}

Environmental TLDs are routinely exchanged at over 90 different locations identified by PNL's environmental monitoring schedule. All the locations are in southeastern Washington and many are on, or adjacent to, the Hanford Site. Soil sampling and germanium spectra data are much less available than TLD data. The TLD data are listed in Table 2 only for those locations where other types of data are available for comparison. These 28 locations (shown in Figure 2) include 7 on the Hanford Site, 10 on the perimeter of the Site, and 11 at area city and community locations. The locations chosen for comparing the monitoring data are representative of the larger group of TLD stations.

The average doses from TLD measurements for the periods 1983 to 1987 and 1988 are listed in Table 2. Average yearly TLD doses for the 5-year period (1983 to 1988) are $80 \mathrm{mrem}, 83 \mathrm{mrem}$, and 72 mrem for onsite, perimeter, and community locations, respectively. A $7 \%$ increase was reported for 1988 compared with the 5-year average.

The results are affected by variations in the sensitivity of the individual TLDs, zero-dose readings, fading, and self-dosing. The zero-dose reading is that portion of the environmental TLD readout signal that is not due to environmental exposure or self-dosing. The yearly average environmental TLD dose may change by 4 or $5 \%$ because of zero-dose corrections. Fading is the loss of stored energy from the TLD prior to readout. The fading process increases with temperature, but is otherwise somewhat analogous to radioactive decay. Fading of dosimeter signal is probably not significant on a monthly basis. Calibration dosimeters are exposed at the mid-cycle of the environmental exposure, such that any fading is automatically compensated for in the calibration factor. Self-dosing refers to the dose the TLD receives from radioactive material included in the $\mathrm{CaF}_{2}: \mathrm{Mn}$, from which the TLD is produced (Lucas and Kapsar 1986). Self-dosing might be suspected if a new batch of TLDs were placed into service to measure environmental background and an increase in readings were noted compared with a previous batch of TLDs. Self-dosing should not exceed 3\% of a typical 1-month environmental TLD exposure. Self-dosing in excess of $3 \frac{\%}{6}$ is ample reason to reject a group 
of TLDs. However, errors due to readout equipment or procedure can easily be mistaken for self-dosing.

With the uncertainties described above, the difference between the yearly average dose to dosimeters at a single location and the maximum or minimum monthly dose is typically less than 25\% of the average. Perhaps 6 to $8 \%$ of the difference (monthly versus yearly) at a single TLD location is due to actual seasonal variations in the dose rate (Burch et al. 1964). Yearto-year variations at a single location are small when the results are adjusted for the differences described above. The difference between the combined yearly average TLD dose at similar locations and any one location's yearly average is less than $12 \%$.

\section{RADIONUCLIDES IN SOIL SAMPLES}

Doses derived from soil samples are also listed in Table 2. The radionuclide activities per gram of soil sample are listed in Table 3 . The locations listed for soil samples are the same as those for germanium spectra and TLDs. However, it is important to note that in some cases soil samples were collected hundreds of meters away from TLD sites because open soil was not available for sampling near the TLD sites. This was especially true at community locations. The doses due to the activity measured in the soil samples were calculated using the same factors used for the germanium spectra (Helfer and Miller 1988). A cosmic radiation dose of $30 \mathrm{mrem} / \mathrm{yr}$ was added to each soil sample dose. Total yearly doses averaged $84 \mathrm{mrem}, 88 \mathrm{mrem}$, and $78 \mathrm{mrem}$ for onsite, perimeter, and community locations, respectively.

Table 2 lists the relative dose of the soil sample (percent of total terrestrial dose) for $40 \mathrm{~K}$, the uranium series, and the thorium series. The average $40 \mathrm{~K}$ dose is approximately $46 \%$, the thorium dose is $42 \%$, and the uranium dose is $13 \%$ of the total for each location category. As reported earlier, this dose represents only approximately one-half the total uranium. 
TABLE 2. Environmental Doses Derived from Detectors, Soil, and TLDs

\begin{tabular}{|c|c|c|c|c|c|c|c|}
\hline Location & $\begin{array}{c}\text { Ge } \\
\text { Detectors, } \\
\text { mrem/yr } \\
\end{array}$ & $\begin{array}{c}\mathrm{Ge} \\
\mathrm{K}: \mathrm{U}: \mathrm{Th} \\
\text { Dose } \\
\text { Ratio } \\
\end{array}$ & $\begin{array}{c}\text { Soil, } \\
\text { mrem/ } \\
\text { yr } \\
\end{array}$ & $\begin{array}{c}\text { Soil } \\
\text { K:U:Th } \\
\text { Dose } \\
\text { Ratio } \\
\end{array}$ & $\begin{array}{c}1983-87 \\
\text { TLO } \\
\end{array}$ & $\begin{array}{l}1988 \\
\text { TLD }\end{array}$ & $\mathrm{NaI}$, \\
\hline \multicolumn{8}{|l|}{ Perimeter } \\
\hline $\begin{array}{l}\text { Pettett } \\
\text { Yakima Barricade } \\
\text { Fir Road } \\
\text { Byers Landing } \\
\text { Sagemoor } \\
\text { Vernita Bridge } \\
\text { Sage Hill } \\
\text { Berg Ranch } \\
\text { Wakluke } 2 \\
\text { Ringold }\end{array}$ & $\begin{array}{l}95 \\
91 \\
85 \\
79 \\
\\
82 \\
80 \\
97 \\
95\end{array}$ & $\begin{array}{l}41: 20: 39 \\
38: 23: 39 \\
45: 19: 37 \\
49: 23: 28 \\
43: 24: 33 \\
51: 18: 31 \\
39: 26: 35 \\
40: 23: 37\end{array}$ & $\begin{array}{l}87 \\
87 \\
89\end{array}$ & $\begin{array}{l}46: 10: 44 \\
53: 12: 35 \\
46: 16: 38\end{array}$ & $\begin{array}{l}78 \\
89 \\
82 \\
82 \\
80 \\
83 \\
77 \\
85 \\
84 \\
83 \\
\end{array}$ & $\begin{array}{l}84 \\
91 \\
86 \\
86 \\
86 \\
90 \\
86 \\
93 \\
87 \\
93 \\
\end{array}$ & $\begin{array}{l}79 \\
81 \\
83 \\
81\end{array}$ \\
\hline $\begin{array}{l}\text { Average } \\
\text { Onsite }\end{array}$ & 88 & $44: 22: 34$ & 88 & $45: 13: 43$ & 83 & 88 & 81 \\
\hline $\begin{array}{l}200-E S E \\
\text { East of } 200-E \\
\text { Southeast of FFTF } \\
100 \text { Fire Station } \\
300 \text { South Gate } \\
200-E \text { NC } \\
400-E \text { A } \\
\text { North of } 300 \text { Area } \\
\text { Average }\end{array}$ & $\begin{array}{l}76 \\
71\end{array}$ & $\begin{array}{l}44: 28: 28 \\
46: 26: 29\end{array}$ & $\begin{array}{l}75 \\
83 \\
78 \\
83 \\
86 \\
86\end{array}$ & $\begin{array}{l}49: 11: 39 \\
42: 19: 38 \\
47: 11: 42 \\
44: 13: 43 \\
42: 18: 40 \\
42: 12: 46 \\
39: 36: 25 \\
46: 13: 41\end{array}$ & $\begin{array}{l}83 \\
85 \\
78 \\
78 \\
78 \\
82 \\
76 \\
-80\end{array}$ & $\begin{array}{l}85 \\
90 \\
85 \\
81 \\
82 \\
82 \\
83 \\
-84\end{array}$ & $\begin{array}{l}79 \\
\underline{83} \\
\end{array}$ \\
\hline \multicolumn{8}{|l|}{ Offsite } \\
\hline $\begin{array}{l}\text { Walla Walla } \\
\text { Pasco } \\
\text { Connell } \\
\text { Sunnyside } \\
\text { Prosser } \\
\text { Yakima } \\
\text { Othello } \\
\text { Moses Lake } \\
\text { Kennewick } \\
\text { McNary } \\
\text { Benton City }\end{array}$ & $\begin{array}{l}64 \\
79 \\
76\end{array}$ & $\begin{array}{l}46: 23: 30 \\
40: 24: 36 \\
42: 19: 39\end{array}$ & $\begin{array}{l}89 \\
78 \\
75 \\
82 \\
85 \\
63\end{array}$ & $\begin{array}{l}46: 11: 43 \\
49: 9: 42 \\
45: 10: 45 \\
41: 16: 43 \\
48: 7: 46 \\
56: 6: 39\end{array}$ & $\begin{array}{l}74 \\
73 \\
72 \\
72 \\
71 \\
68 \\
67 \\
66 \\
79 \\
78 \\
69 \\
\end{array}$ & $\begin{array}{l}85 \\
77 \\
82 \\
76 \\
81 \\
72 \\
74 \\
72 \\
85 \\
86 \\
73 \\
\end{array}$ & $\begin{array}{l}76 \\
\underline{69} \\
\end{array}$ \\
\hline Average & 71 & $44: 24: 33$ & 78 & $47: 11: 42$ & 72 & 78 & 72 \\
\hline
\end{tabular}


TABLE 3. Radionuclide Concentrations in Soil, $\mathrm{pCi} / \mathrm{g}$

\begin{tabular}{|c|c|c|c|}
\hline Location & $K-40$ & $u$ & Ih \\
\hline \multicolumn{4}{|l|}{ Perimeter } \\
\hline $\begin{array}{l}\text { Pettett } \\
\text { Yakima Barricade } \\
\text { Fir Road } \\
\text { Byers Landing } \\
\text { Sagemore } \\
\text { Vernita Bridae }\end{array}$ & $\begin{array}{l}17 \\
17 \\
19 \\
17\end{array}$ & $\begin{array}{l}0.3 \\
0.5 \\
0.3 \\
0.4 \\
0.6\end{array}$ & $\begin{array}{l}1.0 \\
0.8 \\
0.9 \\
0.9\end{array}$ \\
\hline $\begin{array}{l}\text { Sage Hill } \\
\text { Berg Ranch } \\
\text { Wakluke } \$ 2 \\
\text { Ringold }\end{array}$ & $\begin{array}{l}17 \\
14 \\
17 \\
-\end{array}$ & $\begin{array}{l}0.3 \\
0.4 \\
0.7 \\
\end{array}$ & $\begin{array}{l}0.9 \\
1.0 \\
1.4 \\
\end{array}$ \\
\hline Average & 17 & 0.4 & 1.0 \\
\hline \multicolumn{4}{|l|}{ Onsite } \\
\hline $\begin{array}{l}200-\text { ESE } \\
\text { East of } 200-E \\
\text { Southeast of FFTF } \\
100 \text { Fire Station } \\
300 \text { South Gate } \\
200-E \text { NC } \\
400-E \\
\text { North of } 300 \text { Area }\end{array}$ & $\begin{array}{l}14 \\
14 \\
14 \\
15 \\
15 \\
15 \\
14 \\
\underline{16}\end{array}$ & $\begin{array}{l}0.3 \\
0.6 \\
0.3 \\
0.4 \\
0.6 \\
0.4 \\
0.3 \\
1.4\end{array}$ & $\begin{array}{l}0.7 \\
0.8 \\
0.8 \\
0.9 \\
0.9 \\
1.0\end{array}$ \\
\hline Average & 15 & 0.4 & 0.8 \\
\hline \multicolumn{4}{|l|}{ Offsite } \\
\hline $\begin{array}{l}\text { Walla Walla } \\
\text { Pasco }\end{array}$ & 17 & 0.4 & 1.0 \\
\hline $\begin{array}{l}\text { Connell } \\
\text { Sunnyside } \\
\text { Prosser }\end{array}$ & $\begin{array}{l}15 \\
13\end{array}$ & $\begin{array}{l}0.3 \\
0.3\end{array}$ & $\begin{array}{l}0.8 \\
0.8\end{array}$ \\
\hline $\begin{array}{l}\text { Yakima } \\
\text { Othello } \\
\text { Moses Lake }\end{array}$ & $\begin{array}{l}13 \\
16 \\
11\end{array}$ & $\begin{array}{l}0.5 \\
0.2 \\
0.1\end{array}$ & $\begin{array}{l}0.5 \\
1.0 \\
0.5\end{array}$ \\
\hline Kennewick & - & & \\
\hline Average & 14 & 0.3 & \\
\hline
\end{tabular}




\section{COMPARISONS OF YEARLY ENVIRONMENTAL DOSES}

For the locations listed in Table 2, the average doses measured by all devices were quite similar. The difference of less than $8 \%$ between the average $\mathrm{NaI}$ readings and soil sample results was the largest noted for perimeter locations. There was a $9 \%$ difference between the average onsite dose from gamma spectra and the 1988 onsite TLD average. This constituted the largest difference seen for onsite measurements. The same comparison for average city and community measurements also showed a difference of $9 \%$. For all three location categories, the soil sample average results and 1988 TLD average results were nearly identical.

The data in Table 2 show the similarity of the contribution of $40 \mathrm{~K}$ to the total dose for both spectral and soil sample doses. However, the soil samples had a much lower dose contribution from the uranium series and a much higher dose contribution from the thorium series relative to the in situ spectral analyses. This may result from a greater loss of radon from the small samples, as well as less self-attenuation for the lower-energy gamma rays from the thorium series.

The Hanford perimeter doses shown in Table 2 are very similar to those listed in a U.S. Environmental Protection Agency (EPA) report (Oakley 1972) for nonurban areas in Washington State. This is because the 6-mrem/yr reduction in cosmic ray dose just offsets a 6 -mrem/yr increase in terrestrial dose. A paper presented at the Symposium on Natural Radiation Environment (Johnson et al. 1982) reported an annual environmental dose of 70 to $80 \mathrm{mrem} / \mathrm{yr}$ for Washington State. This range of values agrees with most measurements listed in Table 2 for the Hanford Site and communities in southeastern Washington. Dose rates measured at Seattle and Spokane by the Washington Department of Social and Health Services in 1985 were $56 \mathrm{mrem} / \mathrm{yr}$ and $88 \mathrm{mrem} / \mathrm{yr}$, respectively (WDSHS 1987). A recent publication (NCRP 1987) implies an average outdoor absorbed dose of $77 \mathrm{mrem} / \mathrm{yr}$ for the United States (excluding the coastal plain and Rocky Mountain states). The below-average thorium concentrations and low concentrations of uranium in the soil on and near the Hanford Site are more than offset by increased concentrations of 
potassium, such that the environmental doses should be similar to the national average. The values in Table 2 agree with this.

The Hanford environmental monitoring annual reports prior to the 1987 report listed average annual doses to environmental TLDs on and near the Hanford Site in the range of 60 to $72 \mathrm{mrem} / \mathrm{yr}$ (Price and Carlisle 1985; Price 1986; Pacific Northwest Laboratory 1987). These values are thought to have been subject to procedural biases that led to underestimates of the actual doses: When these biases were corrected, the pre-1987 doses agreed with the 1987 values. 


\section{CONCLUSIONS AND RECOMMENDATIONS}

Given the currently accepted values of $30 \mathrm{mrem} / \mathrm{yr}$ for the outdoor ionizing component of cosmic radiation and the activity-to-dose conversion factors of Helfer and Miller (1988), the best estimate of the average annual background dose on the Hanford Site is $80 \mathrm{mrem} / \mathrm{yr}$. The dose at the site perimeter locations is approximately $10 \%$ higher, mostly because of naturally occurring higher concentrations of potassium and thorium. No increases in offsite dose due to Hanford operations were found. The dose in surrounding cities and communities is approximately $7 \%$ lower than the onsite dose because of the pavement and gravel surfaces at the community and city TLD sites.

The environmental doses reported in this report are approximately $10 \mathrm{mrem} / \mathrm{yr}$ higher than the historical doses reported for TLD measurements on the Hanford Site and in the surrounding areas. This difference apparently arises from the smaller corrections now made to the raw TLD readings. The smaller corrections seem to be justified because TLD doses now agree with doses derived from other measurements. It can also be argued that the former TLD doses seemed to agree with other measurement data from the past. The lower activity-to-dose correction factors used in the past would have predicted lower doses from spectral data. Soil sample data for thorium and potassium at Hanford were rather limited until recent years. A few pressurized ionization chamber (PIC) readings were available, but the calibrations were not sufficiently accurate at low doses to detect a difference of $10 \mathrm{mrem} / \mathrm{yr}$.

Measurements of environmental radiation doses at Hanford with germanium spectrometers and $\mathrm{NaI}$ detectors provide instantaneous readings. Averages of these instantaneous readings can provide an estimate of long-term trends. Thermoluminescent dosimeters actually integrate the dose over longer intervals. To better correlate measurements with the various devices, it is recommended that numerous readings be taken throughout the year with germanium and $\mathrm{Nal}$ detectors. Soil samples should be analyzed for total uranium. Additionally, continuous monitoring of a few selected locations should be performed with PICs that have been precisely calibrated to measure $10-\mu \mathrm{R} / \mathrm{h}$ dose rates. One of these devices should be used to measure the dose 
rate several times a year in the middle of the Columbia River below Richland to assess the dose from cosmic radiation.

Thermoluminescent dosimeters placed at city and community locations should be moved away from paved and graveled areas and other disturbed locations that would not reflect the true natural radiation background for the area. This would allow for a more valid comparison of hanford and offsite doses. 


\section{REFERENCES}

American National Standards Institute (ANSI). 1978. Calibration and Usage of Germanium Detectors for Measurement of Gamma-Ray Emission of Radionuclides. ANSI N42.14-1978, New York, New York.

Beck, H. L., J. DeCampo, and C. V. Gogolak. 1972. In Situ Ge(LI) and Na(Tl) Gamma-Ray Spectrometry. HASL-258, U.S. Department of Energy, Environmenta! Measurements Laboratory, New York.

Burch, P. R. J., J. C. Duggleby, B. Oldroyd, and F. H. Spiers, 1964. "Studies of Environmental Radiation of a Particular Site with a Static $\gamma$-Ray Monitor." In The Natural Radiation Environment, eds. J. A. S. Adams and W. M. Lowder, pp. 767. Rice University, Houston, Texas.

Carmichael, H., and M. Berrovitch. 1969. "Analysis of IQSY Cosmic Ray Survey Measurements." Can. J. Phys. 47:2073.

Cutshall, N. H., and I. L. Larson. 1986. "Calibration of a Portable Intrinsic Ge 7 -ray Detector Using Point Sources and Testing for Field Applications." Health Phys. 51:53-59.

Helfer, I. K., and K. M. Miller. 1988. "Calibration Factors for Ge Detectors Used for Field Spectrometry." Health Phys. 55:15-29.

Jaquish, R. E., and P. J. Mitchell. 1988. Environmental Monitoring at Hanford for 1987. PNL-6464, Pacific Northwest Laboratory, Richland, Washington.

Jasinska, M., T. Niewiadomski, and J. Schwabenthan. 1982. "Correlation Between Soil Parameters and Natural. Radioactivity," p. 206 in Natural Radiation Environment, eds. K. G. Vohra, K. C. Pillai, V. C. Mishra, and S. Sadisivan, p. 206. Second Special Symposium on Natural Radiation Environment, Department of Atomic Energy and Indian Association for Radiation Protection, Bombay, India.

Johnson, R. H., Jr., N. S. Nelson, A. S. Goldin, and T. F. Gesell. 1982. "Natural Radiation Quality of the Environment in the United States," In Natural Radiation Environment, eds. K. G. Vohra, K. C. Pillai, V. C. Mishra, and S. Sadisivan, p. 180. Second Special Symposium on Natural Radiation Environment, Department of Atomic Energy and Indian Association for Radiation Protection, Bombay, India.

Lóbbrg, L., L. Botter-Jensen, E. M. Christiansen, and B. L. Nielsen. 1978. "Gamma-Ray Measurements in an Area of High Natural Radioactivity." In Natural Radiation Environment III, Vol.2, eds. T. F. Gesell and W. M. Lowder, Report CONF-780422, U.S. Department of Energy Health and Environment Research, Washington, D.C. and University of Texas School of Public Health, Houston, Texas. 
Lowder, W. M., H. L. Beck, P. D. Raft, G. de P. Burke, C. V. Gogolak, J. A. DeCampo, and J. E. McLaughlin. 1972. "Experimental Investigations of the Environmental Radiation Field." In Natural Radiation Environment II, eds. J. A. S. Adams, W. M. Lowder, and T. Gesell, P. 255. Report CONF-720805, U.S. Energy Research and Development Administration, Washington, D.C.

Lucas, A. C., and B. M. Kapsar. 1986. "The Control of Background in the Production of TL Dosimeters." Rad. Prot. Dos. 17:419-422.

National Council on Radiation Protection and Measurements (NCRP). 1976. Environmental Radiation Measurements. Report Ho. 50, Bethesda, Maryland.

National Council on Radiation Protection and Measurements (NCRP). 1987. Ionizing Radiation Exposure of the Population of the United States. Report No. 94, Bethesda, Maryland.

Oakley, D. T. 1972. National Radiation Exposure in the United States. Report ORP/SID 72-1, U.S. Environmental Protection Agency, Washington, D.C.

O'Brien, K. 1972. "The Physical Theory of One-Dimensional Galastic CosmicRay Propagation in the Atmosphere." In Proc. Nat 1. Symp. on Natural and Manmade Radiation in Space, E. A. Warman, ed., p. 926, NASA TM X-2440 National Aeronautics and Space Administration, Washington, D.C.

Pacific Northwest Laboratory. 1987. Environmental Monitoring at Hanford for 1986. PNL-6120, Richland, Washington.

Price, K. R., and J. M. V. Carlisle. 1985. Environmental Monitoring at Hanford for 1984. PNL-5407, Pacific Northwest Laboratory, Richland, Washington.

Price, K. R. 1986. Environmental Monitoring at Hanford for 1985. PNL-5817, Pacific Northwest Laboratory, Richland, Washington.

Washington State Department of Social and Health Services (WDSHS). 1987. Environmental Radiation Program, Twenty-Fourth Annual Report. Office of Radiation Protection, 0lympia, Washington. 